УДК 811.111

DOI: 10.33184/YVDK-2021-04-30.32

А.В. Уразметова (проф. БашГУ, г. Уфа), К.А. Кагарманова (студ. БашГУ, г. Уфа)

\title{
МОТИВАЦИОННАЯ СПЕЦИФИКА ПРОЗВИЩ БРИТАНСКИХ МОНАРХОВ
}

Статья посвящена выявлению мотивационных особенностей прозвищных номинаций британских монархов. Проводится классификация исследуемых единиц на основе мотивирующего признака номинации. Исследуется коннотативная и эмотивная спецฺифика представленных единиц.

Ключевые слова: ономастика, антропоним, прозвище, вторичная номинация, эмотивность.

The article is devoted to the identification of the motivational features of the nicknames of British monarchs. The classification of the studied units is carried out on the basis of the motivating feature of the nomination. The connotative and emotive specifics of the presented units are investigated.

Key Words: onomastics, anthroponym, nickname, secondary nomination, emotivity.

Актуальность данного исследования обусловлена неугасающим интересом исследователей к именам собственным. Объясняется это тем, что всё, что окружает человека в повседневной жизни, имеет своё имя. Наука, занимающаяся изучением имен собственных, называется ономастикой. Предмет изучения ономастики довольно обширный, а сама наука имеет множество подразделов, одним из которых является антропонимика. Данный раздел занимается изучением антропонимов, к которым относятся личные имена людей, отчества, фамилии, прозвища и т.д. Целью данного исследования является рассмотрение антропонимических прозвищ членов 
британской королевской семьи, выявление их особенностей и обозначение основных мотивирующих признаков их появлений. Материалом исследования служит родословное древо королей Англии и Британии. Теоретическая база исследования основана на работах Д.И. Ермоловича, В.А. Никонова, О.Н. Новиковой, Р.3. Мурясова, А.В. Суперанской, А.В. Уразметовой [1-5] и др.

Антропонимы несут в себе информацию о том, является ли носитель антропонима человеком (например, Jane в отличие от New York); содержат указание на принадлежность человека к какой-то конкретной национально-языковой общности (например, William (англ.) в отличие от Wilhelm (франц.); указывают на пол человека (например, Victoria (жен.) и John (муж.)).

В лингвистической литературе выделяются следующие типы антропонимов:

1) личное имя;

2) фамилия;

3) отчество;

4) андроним (именование женщины по имени, фамилии или прозвищу её мужа);

5) мононим (полное имя человека, состоящее из одного слова, вместо привычных имени, фамилии и отчества);

6) никнейм (сетевое имя, используемое человеком в сети Интернет);

7) прозвище (имя, которое человеку дали окружающие в соответствии с какой-либо его чертой, это может быть особенность внешности, характера, или жизненные обстоятельства и т.д.);

8) псевдоним (вымышленное имя, используемое в публичной деятельности вместо настоящего);

9) криптоним (подпись под произведением вместо имени автора, т.е. имя, рассчитанное на то, чтобы скрыть подлинного автора произведения);

10) антропонимы литературных произведений, героев в фольклоре, в мифах, сказках;

11) эпоним (лицо, от имени которого образованы имена нарицательные или другие имена собственные);

12) ономатет (представление мифологического или философского образа божества или человека, дающего и 
устанавливающего имена всему сущему, либо отдельным предметам или живым существам).

В русской ономастике прозвище рассматривают как вид антропонима, которое представляет собой дополнительное имя, данное человеку окружающими в соответствии с его характерной чертой, сопутствующим его жизни обстоятельствам или по какойлибо аналогии [Ермолович 2001: 38]. Для лингвистов, изучающих прозвища с этой точки зрения, чаще всего наибольший интерес представляют причины возникновения того или иного прозвища: чем оно мотивировано, конкретные причины, почему тот или иной человек получил это прозвище.

Следует отметить, что одни прозвища люди действительно получают в соответствии с их характерными чертами, такими как внешность или характер и др., другие же прозвища могут казаться совершенно немотивированными (чаще всего это отфамильные прозвища типа Rocky от Rockefeller и т.п.).

При отнесении прозвища к тому или иному типу, можно использовать следующие критерии:

1) зависимость прозвища от ситуации;

2) состав прозвища;

3) характер коммуникативной сферы, в которой прозвища становятся индивидуальными;

4) степень характеризации референта.

Антропонимические прозвища имеют свои отличительные признаки. Они относятся к человеку и отражают какие-либо особенные черты, выделяющие его в определенной социальной группе. Очень часто человек имеет несколько прозвищ, употребляемых в разных кругах общения. Таким образом, следует подчеркнуть, что прозвище является отражением общественного мнения о том или ином индивидууме.

Результаты проведенного анализа исследуемой лексики позволили выявить пять самых многочисленных групп мотивирующих признаков:

1) по внешним признакам: Edwig All-Fair (Kpacuвbiü), William II Rufus (Pыжий), Edward I Longshanks (Длиноногий), Edmund Crouchback (Горбатьіи);

2) по личным качествам: 
Edward the Confessor (Исповедник) - при жизни правитель был ярым приверженцем аскетизма, впоследствии был канонизирован;

Henry I Beauclerc (Грамотей) - прозвище правитель получил за свою ученость;

Richard I the Lionheart (Львиное сердие) - свое прозвище правитель получил благодаря своей репутации смелого и бесстрашного воина;

\section{3) по особенностям правления и политической} деятельности:

Eadgar the Peaceable (Миролюбивый) - монарх получил свое прозвище за то, что избегал военные конфликты;

Alfred the Great (Великий) - прозвище этого монарха объясняется его огромным вкладом в становление Английского государства, при его правлении произошло объединение большей части англосаксонских королевств;

Etelstan the Glorious (Славный) - правитель монарх получил вследствие своих выдающихся заслуг: при нем впервые все Английские земли оказались под властью одного правителя;

Ethelred II Unready (Неразумный) - свое прозвище этот монарх получил в результате своей недальновидной политики;

William I the Conqueror (Завоеватель) - данное прозвище правитель получил за завоевание Английского престола;

Mary I (Кровавая) - это прозвище королева получила в результате своих жестких мер по установлению католичества в стране, и поскольку во время её правления произошло много казней протестантов;

Richard I Yes-and-No (Pичард «Дa-u-Hem») - в прозвище этого монарха находит отражение тот факт, что его легко было склонить в ту или иную сторону;

Eadmund II Ironside (Железнобокий) - это прозвище монарх получил в результате своего упорного противостояния датскому завоеванию;

Edward VII the Peacemaker (Mиротвореч) - свое прозвище правитель получил за огромный вклад во внешнюю и внутреннюю политику Англии;

4) по месту рождения: Henry III of Winchester (Buнчестер), Edward II of Carnarvon (Карнарворн), Edward III of Windsor (Виндзорский); 


\section{5) по историческому событию или факту из жизни}

\section{монархов:}

Edward II the Martyr (Мученик) - это прозвище монарх получил после своей трагической смерти: он был жестоко убит, и в последствии стал почитаться святым в католичестве и англиканстве;

Lady Jane Grey (Девятидневная королева) - прозвище королевы связано с тем, что ее правление продлилось всего девять дней;

John Lackland (Безземельный) - при разделе отцовского наследства этому монарху досталось очень мало земель, в связи с чем он и получил данное прозвище;

Elizabeth I (Королева-дева) - свое прозвище королева получила за решение никогда не выходить замуж;

Edward VII the Uncle of Europe (Дядя Европы) - прозвище связано с тем, что монарх приходился дядей нескольким европейским монархам, правившим с ним в одно время.

Таким образом, следует заключить, что представленные вторичные номинации отличаются своей эмотивностью, поскольку в них отражено отношение народа к монарху, народная оценка его деятельности или его личности. Также интересен тот факт, что в некоторых случаях, у монарха было не одно, а сразу несколько прозвищ, причем они могли быть совершенно противоположными по своей эмоциональной окраске (напр. Ричард I имел два прозвища: «Львиное Сердие» за свою храбрость и вклад во внешнюю и внутреннюю политику Англии, и "Да-иHет» за изменчивость его политических взглядов). Несмотря на то, что преимущественно прозвища монархов имеют нейтральную или положительную эмоциональную окраску, в них находит отражение полный спектр эмоций народа, в том числе и отрицательных: так, например, прозвища могут выражать неодобрение или насмешку (нanp. Bloody Mary, Ethelred II Unready).

\section{ЛИТЕРАТУРА}

1. Ермолович, Д. И. Имена собственные на стыке языков и культур/ Д.И. Ермолович. - М.: Р. Валент, 2001. - 200 с. 
2. Мурясов Р.3., Газизов Р.А. Антропонимы в системе языка // Вестник Башкирского университета. 2015. T. 20. № 3. С. 1017-1021.

3. Никонов, В. А. Задачи и методы антропонимики [Текст]: сборник статей / В.А. Никонов // Личные имена в прошлом, настоящем и будущем: Проблемы антропонимики. - М.: Наука, 1970. - С. $33-56$.

4. Новикова О.Н. Имя собственное в энциклопедическом дискурсе // Доклады Башкирского университета. 2019. Т. 4. № 5. С. 554 557.

5. Суперанская А.В. Общая теория имени собственного [Текст]: монография / A. В. Суперанская. - М.: Просвещение, 1973. - 180 с.

6. Уразметова А.В. Школьные прозвища в системе номинативных средств английского языка // Доклады Башкирского университета. 2019. Т. 4. № 5. С. 548-553.

(C) Уразметова А.В., Кагарманова К.А., 2021 г. 